Pregledni rad

UDK: 368.223:347.7>:339.5

Datum primitka članka u uredništvo: 26. 3. 2018.

Datum slanja članka na recenziju: 17. 4. 2018.

Datum prihvaćanja članka za objavu: 21. 11. 2018.

\author{
Dr. sc. Ivana Lovrić*
}

\title{
ULOGA KARGO OSIGURANJA U SUVREMENOJ MEĐUNARODNOJ TRGOVINI
}

\author{
THE ROLE OF CARGO INSURANCE \\ IN INTERNATIONAL TRADE
}

SAŽETAK: U radu se analizira i objašnjava s pravno-ekonomskog stajališta kakva je uloga kargo osiguranja u odvijanju međunarodne trgovine. Argumentirano se ukazuje da ugovor o međunarodnom kargo osiguranju ima obilježja međunarodnog ugovora u subjektivnom i objektivnom smislu. U tom se osiguranju kao osigurani predmet javlja roba koja podrazumijeva svaku tjelesnu pokretnu stvar kao objekt međunarodnog prijevoza.

Sklapanje ugovora o osiguranju robe nije obvezno, ali je u suvremenim uvjetima nezamislivo da roba u prijevozu nije osigurana od transportnih rizika. Dokazuje se da je cjelokupan pravni sustav međunarodne trgovine utemeljen na pretpostavci da postoji osiguranje robe. Posebice se ukazuje na iznimnu važnost isprava o osiguranju u financiranju međunarodne trgovine i kakva je u tom pogledu uloga bankarskog sustava. Prikazom mjera državne politike u zaštiti domaćeg tržišta osiguranja, ukazuje se na važan makroekonomski aspekt djelatnosti osiguranja u međunarodnoj trgovini. Zaključno se naglašava da je međunarodno kargo osiguranje važan element međunarodnog poslovanja te značajno pridonosi njegovu odvijanju i razvoju.

KLJUČNE RIJEČI: ugovor o međunarodnoj prodaji, izvori prava za ugovor o međunarodnoj prodaji, sloboda sklapanje ugovora, interes za osiguranje robe, Incoterms pravila.

SUMMARY: The paper analyzes and explains from a legal and economic point of view, the role of cargo insurance in international trade. It argues, the contract on international cargo insurance has the characteristics of an international contract in a subjective and objective sense. In cargo insurance, as a subject-matter insured are goods in transit, which implies any bodily movable thing acting as an object of international transport.

It's not mandatory to contract the insurance of goods however, in contemporary terms there is an assumption that the goods during transit are insured against transport risks. The

Dr. sc. Ivana Lovrić, poslijedoktorandica, Pomorski fakultet, Sveučilište u Splitu, Ruđera Boškovića 37, 21000 Split 
overall law on international trade is based on the preposition that the cargo insurance contract is made. In particular, there is an emphasis on the importance of insurance documents in financing international trade, and in this respect the role of the banks. State measures in protecting domestic insurance market point to an important macroeconomic aspect of the insurance business in international trade. Accordingly, international cargo insurance is herein underlined as an important element of foreign trade which significantly contributes to its development and growth.

KEY WORDS: international sale contract, law on international sale contract, contracting freedom, insurable interest, Incoterms rules.

\section{UVOD}

Razmjena dobara i usluga oduvijek je prisutna u društvu, razvijala se i rasla usporedno s razvojem tehnologije proizvodnje i prijevoza. Međunarodna trgovina ima izniman društveni i ekonomski značaj, poglavito u današnjem procesu globalizacije. Međunarodna trgovina sve je složenija, s brojnim trgovačko-pravnim poslovima koji pridonose brzini i učinkovitosti njenog odvijanja.

U ovome se radu namjerava s ekonomsko-pravnog stajališta utvrditi uloga koju međunarodno kargo osiguranje ima u međunarodnoj trgovini. Cilj istraživanja jest preispitati, a potom utvrditi i argumentirati na koji način kargo osiguranje doprinosi odvijanju i razvoju vanjskotrgovinskog poslovanja. Također, u radu se namjerava utvrditi važnost isprava o osiguranju u financiranju međunarodne trgovine te kakva je u tom pogledu uloga bankarskog sustava.

Rad je strukturiran u devet poglavlja, s literaturom na kraju. U Uvodu je predstavljen predmet istraživanja rada, njegovi ciljevi te dana je struktura rada. Sljedeće poglavlje uvodi u problematiku ovoga istraživanja putem definiranja i obrade temeljnih obilježja međunarodnog kargo osiguranja. Značenje pojma roba kao osiguranog predmeta obrađeno je u narednom poglavlju. U kargo osiguranju kao osigurani predmet javlja se roba u smislu svake tjelesne pokretne stvari koja je objekt međunarodnog prijevoza. Ugovor o međunarodnom osiguranju robe pruža zaštitu od ugovorenih transportnih rizika za vrijeme prijevoza. Redovito svaku međunarodnu kupoprodaju prate tri potpuno pravno samostalna ugovora: ugovor o prodaji, ugovor o prijevozu i ugovor o osiguranju koji predstavljaju pravni temelj robne razmjene. Ti ugovori su vezani za jedno te istu robnu transakciju te potpomažu odvijanju međunarodne trgovine. Četvrto poglavlje preispituje gospodarski značaj kargo osiguranja u međunarodnoj trgovini. Peto poglavlje ukazuje na ekonomsko-pravnu potrebu za kargo osiguranjem te kako putem osiguranja uspješno upravljati rizicima i ostvariti komercijalnu i financijsku sigurnost. U radu se ujedno preispituje interes za osiguranje robe stranaka iz ugovora o prodaji te kada će prodavatelj ugovoriti osiguranje robe za vrijeme prijevoza.

Važnu ulogu u odvijanju međunarodne trgovine imaju i banke koje financijski prate poslove ili se preko njih obavljaju plaćanja, najčešće uz uporabu dokumentarnog akreditiva. U šestom poglavlju dan je naglasak na ključnu ulogu koju kargo osiguranje ima u financiranju međunarodne trgovine. Ono unosi element sigurnosti u uspješnost posla te potiče banke na donošenje odluke o kreditiranju takve prodaje. Osim toga, u financiranju međunarodne kupoprodaje redovito je polica osiguranja, uz trgovački račun i prijevoznu ispravu, predvi- 
đena bankovnim akreditivnim nalogom. Sklapanje ugovora o osiguranju robe nije obvezno. Sedmo poglavlje rada dokazuje da je cjelokupan pravni sustav kao i financiranje međunarodne trgovine utemeljen na pretpostavci da postoji osiguranje robe. Rad završava prikazom mjera državne politike u zaštiti domaćeg tržišta osiguranja te potvrdom makroekonomskog aspekta kojeg osiguranje ima u međunarodnoj trgovini. Zaključna razmatranja su dana u posljednjem, devetom poglavlju. Međunarodno kargo osiguranje je naglašeno kao važan element međunarodnog poslovanja koji značajno pridonosi njegovu odvijanju i razvoju.

\section{MEĐUNARODNO KARGO OSIGURANJE - POJAM I OSNOVNA OBILJEŽJA}

Pod pojmom međunarodno kargo osiguranje podrazumijeva se osiguranje robe od transportnih rizika u međunarodnom prijevozu. S obzirom na to prevozi li se roba u međunarodnom ili domaćem prijevozu, kargo osiguranje se dijeli i na: međunarodno kargo osiguranje i domaće kargo osiguranje. Međunarodno kargo osiguranje praktično znači osiguranje uvoznih ili izvoznih pošiljaka robe iz neke države. Pojam domaći kargo podrazumijeva osiguranje robe u prijevozu unutar neke državne granice.

U poslovnoj praksi osiguranja koriste se različiti kriteriji za razlikovanje međunarodnog od domaćeg kargo osiguranja. To je važno utvrditi jer se u osiguranju međunarodnog karga koristi posebna standardna prenosiva pomorska polica i posebni uvjeti osiguranja, a premija osiguranja se obračunava prema posebnim tarifama. Najčešće primjenjivani kriterij za utvrđivanje spada li konkretno osiguranje u međunarodno ili domaće jest prijevozna isprava, s uvidom u podatke o osiguranom putovanju. Ako je riječ o međunarodnom teretnom listu ili drugoj prijevoznoj ispravi, a putovanje ima značajke međunarodnog prijevoza, tada je riječ o međunarodnom kargo osiguranju. Međunarodno kargo osiguranje obilježavaju brojne posebnosti.

Kargo osiguranje bitno je obilježeno njegovom međunarodnom naravi, budući da pokriće osiguranjem obično uključuje međunarodno transportiranje robe. Ugovor o osiguranju robe u međunarodnom transportu prema tome ima sva obilježja međunarodnog ugovora. U tome ugovoru postoji međunarodno obilježje u subjektivnom i objektivnom smislu. Njegove su stranke fizičke ili pravne osobe koje pripadaju različitim pravnim sustavima (državama). Objektivno međunarodno obilježje toga ugovora proizlazi iz činjenice što se osigurano putovanje odvija teritorijem jedne ili više stranih država, pa roba u smislu osiguranog predmeta prelazi preko više državnih granica. Kako je ovdje riječ o ugovoru privatnog prava, gdje stranke nisu države, nego trgovci iz različitih zemalja, kod tih se ugovora otvara pitanje primjene (izbora) stranog prava i sudske nadležnosti u slučaju spora među strankama. ${ }^{1}$ Ta se pitanja rješavaju prema pravilima međunarodnog privatnog prava, osim ako nisu ugovornim odredbama posebno riješena.

Međunarodno kargo osiguranje obilježava i činjenica što se u tom osiguranju kao osigurani predmeti često javljaju i robe vrlo visoke vrijednosti, posebice kod masovnih tereta ili specijalnih tereta visoke tehnološke vrijednosti. Zbog toga je moguće da vrijednosti tih

O pojmu „međunarodni“ ugovor opširnije Gorenc, Vilim, Schwank, Friedrich, Slakoper, Zvonimir, Međunarodna pravila za kupoprodaju, plaćanja i arbitraže, RRif, Zagreb, 1996., str. 4. 
tereta premašuju kapacitet domaćeg tržišta osiguranja, pa je nužno vrijednosti iznad kapaciteta toga tržišta ili pojedinog osiguratelja, suosigurati ili reosigurati, najčešće na svjetskom tržištu reosiguranja. U takvu slučaju može doći do primjene pravila i običaja prema kojima djeluje to tržište, a moguće je da reosiguratelj uvjetuje i neke posebne uvjete osiguranja.

Za međunarodno kargo osiguranje je karakteristično da se pri sklapanju ugovora o osiguranju ugovara primjena stranih standardnih uvjeta osiguranja. To su prije svega standardne zbirke klauzula engleskog tržišta osiguranja poznate pod nazivom Institute Cargo Clauses (I.C.C.). U tom se osiguranju nekada koristila i engleska standardna pomorska polica osiguranja - Lloyd's S.G. Policy Form. Primjena te police je zbog njene zastarjelosti danas napuštena. Kod nas su danas u uporabi pomorske police domaćih osiguratelja, koncipirane po uzoru na tzv. Novu englesku pomorsku policu - New Marine Policy Form - Form MAR iz 1982.

Međunarodna kupoprodaja u klasičnom primjeru realizira se prijevozom robe iz unutrašnjosti jednog kontinenta, prijevozom morem i prijevozom kopnom do neke točke u unutrašnjosti nekog drugog kontinenta. To znači da se prijevoz obavlja pomoću više vrsta prometa. Unatoč tome, u suvremenim se uvjetima takav prijevoz najčešće obavlja na temelju samo jednog ugovora - ugovora o multimodalnom (višenačinskom) prijevozu. U takvim se situacijama glavni teret pretežito prevozi u kontejnerima, što se odražava i na odnose iz ugovora o osiguranju robe. Na primjer, premije su za kontejnerizirani teret niže; prijevoz na palubi kontejnerskog broda smatra se uobičajenim načinom prijevoza i nije ga potrebno dodatno osigurati zbog povećanog rizika i sl.

\section{ROBA (TERET) KAO OSIGURANI PREDMET}

U osiguranju robe kao osiguranog predmeta javlja se roba u smislu objekta prijevoza - teret (kargo). Izrazom „CARGO općenito se označava trgovačka roba koja se prevozi brodom ili zrakoplovom ili kopnenim prijevoznim sredstvom. “2 Zato se to osiguranje uobičajeno naziva kargo osiguranje (engl. marine cargo insurance). Slično tome, pomorska polica za osiguranje robe naziva se pomorska kargo polica (engl. marine cargo policy). Hrvatski Pomorski zakonik (u nastavku i PZ, 2004.) poznaje pojam osiguranje robe, ali ne sadrži definiciju toga pojma. Takvu definiciju nalazimo u engleskom Marine Insurance Act-u iz 1906. (MIA, 1906.). Prema Rules for Construction of Policy, First Schedule uz MIA, 1906. izraz ,goods“ podrazumijeva robu trgovačke naravi (trgovačku robu; merchandise) te ne uključuje osobne stvari posade i putnika kao ni namirnice ili zalihe materijala namijenjenih za uporabu na brodu (t. 17.). Marine Insurance Act poznaje i pojam movables (goods ormovables) i pod tim pojmom podrazumijeva ,svaku tjelesnu pokretnu stvar, osim broda te uključuje novac i vrijednosna jamstva i drugu dokumentaciju“ (čl. 90.).

Suvremeno značenje pojma „roba“ (goods) u smislu osiguranog predmeta šire je od uobičajenog značenja toga izraza. „Pod pojmom roba iz kargo osiguranja nije obuhvaće-

Prema Sullivan, Eric, The Marine Encyclopedic Dictionary, London, 1988. Opširnije o značenju pojma „kargo“ v. Pavić, Drago, Pomorsko osiguranje. Pravo i praksa, Književni krug, Split, 2012., str. 276. 278.; Croatia osiguranje, Osiguranje robe u prijevozu, internetski izvor http://www.crosig.hr/hr/osiguranja/plovila-prijevoz-i-krediti/osiguranje-robe-u-prijevozu/ (31/05/2018). 
na samo roba u smislu stvari u trgovačkom prometu, nego svaka tjelesna pokretna stvar koja se prevozi ili prenosi. Pritom nije od važnosti priroda stvari, njen oblik, težina, način njezina pakiranja, kao ni vrijednost odnosne stvari. U okviru toga osiguranja moguće je za vrijeme prijevoza ili prijenosa osigurati i novac, drago kamenje, nakit, vrijednosne papire, filatelističke i numizmatičke zbirke i sl.“3 Pojmom roba obuhvaćena je i komercijalna ambalaža robe. Prema engleskom pravu, općim pojmom „roba“ (goods) nije obuhvaćena roba koja se prevozi na palubi broda $i$ žive životinje, osim ako takav prijevoz nije uobičajen pa je u nedostatku takvog običaja, teret smješten na palubi broda potrebno posebno osigurati (t. 17. Rules for Construction of Policy).

Osigurljiva vrijednost robe (vrijednost osigurljivog interesa) određuje se prema posebnim pravilima (engl. measure of insurablevalue). Ta pravila uvažavaju činjenicu da je, s komercijalnog stajališta promatrano, za određivanje visine osigurljivog interesa bitna ona vrijednost koju roba ima na odredištu, a ne u polaznom mjestu, tj. na početku osiguranog putovanja. Zato se prema pravilima poredbenopravnih sustava i poslovne prakse, za određivanje osigurljive vrijednosti robe uzima u obzir ne samo stvarna (tržišna) vrijednost robe u polaznom mjestu, nego i brojni drugi troškovi koji pridonose njezinoj konačnoj tržišnoj vrijednosti. Prema hrvatskom Pomorskom zakoniku, na primjer, istim se ugovorom mogu osigurati osim robe i očekivana dobit, trošak osiguranja, vozarina i drugi troškovi u vezi s prijevozom i isporukom robe (čl. 731.).

U polici osiguranja roba se kao osigurani predmet označava pojedinačno ili generično. Roba se pojedinačno označava tako da se, osim osiguranog predmeta (prema vrsti robe, pakiranju i dr.) u polici, navedu i njegove identitetne oznake. Ako se roba prevozi u kontejneru, vagonu ili slično, kao element individualizacije te robe redovito služe identitetne oznake i brojevi tih sredstava pa se osim oznake vrste robe i ti podaci unose u policu. Roba se generično označava navođenjem vrste robe. Na primjer, pšenica, kukuruz i sl. Ako su stranke ugovorile količinu robe ili je količina bitna za individualizaciju osigurane robe, polica osiguranja mora sadržavati i taj element. ${ }^{4}$

Roba se prema vrsti i svojstvima može klasificirati u više grupa. Neke su robe međusobno slične prema vrsti, podrijetlu, prirodnom svojstvu, namjeni, pakiranju, obliku, načinu rukovanja, izradi-konstrukciji pa čine ,cargo families“. U literaturi se navode ove glavne „,kargo familije“: grain, agriculture, timber, coal, fertiliser, cement, ferrous ore, minerals, metals, chemicals, reefer, livestock \& animal products, liquid \& gas and dangerous goods. ${ }^{5}$ Roba se može razvrstati i prema prirodnoj osjetljivosti (sklonosti) za nastanak određenih vrsta šteta za vrijeme prijevoza zbog njihovog prirodnog svojstva (lom, rasipanje, curenje, sušenje, znojenje, zapaljenje, samozapaljenje, zagrijavanje, miris i dr.). ${ }^{6}$ Pri sklapanju osiguranja, u polici se ne navodi prirodno svojstvo robe. Taj je rizik uostalom

V. Pavić, Drago, Pomorsko osiguranje. Pravo i praksa, op. cit., str. 276.

Prema Lovrić, Ivana, magistarski znanstveni rad „Nove institutske klauzule za osiguranje robe, 2009.“, str. 14. i tamo cit. literatura.

Vishwanath, K. S., Insuring Cargoes, Witherbys Insurance, Edinburg, 2010., str. 5. Više o klasifikaciji robe prema vrsti, pakiranju i načinu rukovanja te načinu na koji pakiranje utječe na način transporta robe v. Regodić, Dušan, Logistika, Univerzitet Singidunum, Beograd, Srbija, 2014., str. 271. - 273. i 295.

6 Popis roba prema njihovoj osjetljivosti za nastanak određenih šteta v. u Dover, Victor, (rev. R. H., Brown), A Handbook to Marine Insurance, 8. ed., Witherby, London, 1975., str. 174. - 183.; Pavić, Drago, Pomorsko osiguranje. Pravo i praksa, op. cit., str. 157. - 159. 
isključen iz standardnog kargo osiguranja, ali se može dodatno osigurati. S obzirom na to da prirodno svojstvo robe utječe na rizičnost prijevoza, ta se okolnost odražava na potrebu poduzimanja preventivnih mjera ili na visinu premijskih stopa prema tarifi osiguratelja, što uz ostale elemente, kao što su način prijevoza, pakiranja i dr., može utjecati na visinu premije osiguranja.

Prema standardnim uvjetima kargo osiguranja (npr. Institute Cargo Clauses i dr.), osiguranjem je pokriven samo fizički gubitak ili oštećenje osiguranog predmeta, kao i ugovorom predviđeni troškovi i obveze. Financijski gubitci i troškovi (posljedične štete) nisu pokriveni osiguranjem. U Institute Cargo Clauses (1982.; 2009., u nastavku i I.C.C.) izrijekom je predviđeno da osiguranje pokriva „loss of ordamage to“. U sudskoj praksi nedvojbeno je utvrđeno da to znači samo fizički gubitak ili oštećenje osiguranog predmeta, premda u tekstu tih uvjeta ne postoji izraz ,physical“. Izraz „physicalloss or damage“ nije uvršten ni u najnovijoj reviziji tih uvjeta iz 2009. Smatra se da to nije bilo potrebno s obzirom na to da je značenje izraza ,loss of ordamageto" u smislu fizičke štete višekratno potvrđeno u sudskoj praksi. ${ }^{7}$ Drukčije od toga, u američkim standardnim kargo klauzulama izrijekom je navedeno da polica pokriva „All Risks of physical loss or damage from any external cause..." (American Institute (AIMU) Cargo Clauses, 2004. - All Risks). Osim fizičkih šteta, standardnim kargo osiguranjem izrijekom su pokriveni i neki troškovi-izdaci koji padaju na teret osiguranika. To su: doprinos u zajedničku havariju (engl. General Average), nagrade za spašavanje (engl. Salvage), osiguranikovi troškovi spašavanja (engl. Sue and Labour Charges) i obveze prema „Both to Blame Collision Clause ${ }^{68}$ iz ugovora o prijevozu robe morem.

Roba (kargo) se osigurava u smislu objekta prijevoza (ili prijenosa). Postojanje prijevoznog pothvata bitna je pretpostavka za sklapanje ugovora i njegovu valjanost. U okviru ovoga osiguranja, primjerice, nije uopće moguće osigurati robu za vrijeme njena uskladištenja koje nije ni u kakvoj vezi s odvijanjem prijevoznog pothvata. ${ }^{9}$ Prijevozni pothvat utvrđuje se iz sadržaja ugovora. Kod osiguranja na određeno putovanje, obvezni je sastojak police oznaka osiguranog putovanja (engl. voyage). U polici se navode i podaci o prijevoznom sredstvu, posebice imenu broda i drugi podaci potrebni za identifikaciju osiguranog putovanja.

Za osiguranje robe u prijevozu nije uvjet da se roba prevozi na temelju prethodno sklopljenog ugovora o prijevozu. Osigurati se može i stvar u prijevozu, a da za takav prijevoz nije sklopljen ugovor o prijevozu. Riječ je o dva potpuno odvojena pravna posla. Isto tako, ne postoje ni ograničenja u pogledu izbora grane prometa u okviru koje će se prijevoz obaviti, unimodalno ili multimodalno, kao ni u pogledu izbora vozila i njegovih tehničkih obilježja. Isto tako, nevažno je hoće li se roba prevoziti u rasutom stanju, u koletima, komadima ili će se za njen prijevoz upotrijebiti neko sredstvo za grupiranje robe, kao što

Dunt, John, Marine Cargo Insurance, INFORMA, London, 2009., str. 274.

Opširnije v. Pavić, Drago, Pomorsko osiguranje. Pravo i praksa, op. cit., str. 296. - 297.

U okviru pomorskog osiguranja robe u prijevozu, roba je osigurana samo za vrijeme usputnih i privremenih uskladištenja pri izvođenju samog transportnog pothvata i vremenski ograničenog uskladištenja robe u lučkim skladištima prije ili poslije pomorskog prijevoza (v. Transit Clause, I.C.C., 2009.). Opširnije Lovrić, Ivana, Institute Cargo Clauses: Nova verzija 2009., Poredbeno pomorsko pravo, god. 51 (2012.), 166., 2012., str. 351. - 355.; Petrinović, Ranka; Lovrić, Ivana, Trajanje osiguranja prema Institute Cargo Clauses 2009., Naše more, br. 59(3-4)/2012., 2012., str. 142. - 144. 
je kontejner, paleta i sl. Te okolnosti mogu utjecati samo na visinu premije osiguranja ili posebne uvjete osiguranja.

\section{GOSPODARSKO ZNAČENJE KARGO OSIGURANJA}

Gospodarsko značenje pomorskog (transportnog) osiguranja općenito, pa tako i pomorskog kargo osiguranja posebno, temelji se na činjenici da ono pruža sigurnost i zaštitu imovinskih interesa sudionicima pomorskog pothvata kao i sudionicima međunarodne robne razmjene općenito. Zbog toga osiguranje ima iznimno značajnu ulogu u odvijanju i razvoju međunarodne trgovine. ${ }^{10}$ Gospodarska je potreba da se razne robe, proizvodi i sirovine premještaju u geografskom prostoru, najčešće od mjesta proizvodnje ili prirodnog nalazišta do mjesta potrošnje ili prerade. To se ostvaruje različitim načinima prijevoza. Svakom je načinu prijevoza svojstveno postojanje stanovitog stupnja opasnosti da objekt prijevoza slučajno propadne ili se ošteti. Gospodarski je najvažniji pomorski prijevoz, tj. prijevoz robe morem različitim plovnim objektima pa je i uloga osiguranja u tom prijevozu osobito značajna. Plovidbena je djelatnost povijesno od samih početaka bila izložena raznolikim opasnostima, koje su ugrožavale sigurnost ljudi, brodova i brodskih tereta.

Zahvaljujući sigurnosti koju pruža osiguranje, trgovci su se kroz povijest mogli smjelije upuštati u trgovačke poslove bez straha da će zbog možebitne propasti neke robne pošiljke izgubiti svoju imovinu. To je isto vrijedilo i za brodare koji su ulagali velika sredstva u gradnju i nabavu pomorskih brodova. Tako se osiguranje razvijalo usporedo s razvojem trgovine i prometa prilagođavajući svoje uvjete i oblike izmijenjenim tehničkim i ekonomskim okolnostima i potrebama robnog prometa i transporta. ${ }^{11}$ Suvremeni tehnološki napredak pridonio je smanjenju prirodnih opasnosti, ali su one i dalje prisutne pri obavljanju pomorske plovidbe. Osim prirodnih opasnosti, na rizike pomorske plovidbe u suvremenim uvjetima utječu i brojni drugi rizici, kao što su ratni rizici, piratstvo, terorizam i sl. Na povećanje rizika utječe i činjenica što su kapaciteti brodova sve veći, a time su i vrijednosti u riziku sve veće. ${ }^{12}$ To znači da bi u slučaju nastanka neke veće pomorske nezgode, nositelji rizika pretrpjeli gubitke takve naravi i visine da bi to moglo ugroziti njihovu poslovnu i financijsku sposobnost, pa čak i opstanak. Zbog toga je i u suvremenim uvjetima nemoguće zamisliti bavljenje gospodarskim aktivnostima na moru bez odgovarajuće zaštite osiguranjem. Osim toga, praksa suvremenog pomorskog osiguranja omogućuje gospodarstvenicima da osiguraju, ne samo uobičajene transportne rizike, nego i razne dopunske rizike, kao i rizike koji proizlaze iz samog prirodnog svojstva robe.

Važno je naglasiti da zbog ekonomskog značenja osiguranja robe, ono u pravu Europske unije (u nastavku i EU) uživa poseban pravni status. U tom se pravu ono klasificira kao osiguranje ,velikih rizika“ (eng. large risks) pa u odnosima iz osiguranja robe u međunarodnom transportu postoji sloboda u izboru mjerodavnog prava, kao i sloboda u izboru sudske nadležnosti (jurisdikcije). ${ }^{13}$

\footnotetext{
10 O ekonomskom značenju međunarodnog osiguranja, opširnije Frančišković, Ivan, Ekonomika međunarodnog osiguranja, Ekonomski fakultet u Rijeci, Rijeka, 2004., str. 5. i d.

Tomašić, Veljko, Transportno osiguranje, Suvremena administracija, Beograd, 1987., str. 39.

V. Pavić, Drago, Pomorsko osiguranje, Knjiga I, CROATIA OSIGURANJE, Zagreb, 1986., str. 19.

V. hrvatski Zakon o osiguranju iz 2015., čl. 7. t. 7., „osiguranje robe u prijevozu“.
} 
Korisnoj ulozi pomorskog osiguranja posebice pridonosi uporaba pomorske police s obzirom na njeno svojstvo prenosivosti. Prijenosom police osiguranja s prodavatelja na kupca, prenose se i prava iz ugovora o osiguranju, a time i svojstvo osiguranika. ${ }^{14}$

Zbog svega toga pomorsko odnosno transportno osiguranje općenito je važan element međunarodnog poslovanja te značajno pridonosi njegovu odvijanju i razvoju.

Važnu ulogu u odvijanju međunarodne trgovine imaju i banke koje financijski prate poslove ili se preko njih obavljaju plaćanja, najčešće uz uporabu dokumentarnog akreditiva. S tim u vezi, naglašava se da kargo osiguranje igra ključnu ulogu u financiranju međunarodne trgovine. ${ }^{15}$ Međunarodna prodaja robe najčešće je financirana od strane banaka. Sama okolnost da je provedeno osiguranje robe za vrijeme prijevoza, potiče banke pri donošenju odluke da kreditno prate takvu prodaju, jer osiguranje unosi element sigurnosti u uspješnost posla. Osim toga, u financiranju međunarodnog dokumentarnog akreditiva iznimno je važna uloga pomorske police. Njena uloga u dokumentarnoj naplati temelji se na činjenici da predstavlja dokaz o sklopljenom ugovoru o osiguranju i o njegovu sadržaju te da pruža odgovarajuću pravnu sigurnost pri prijenosu police na kupca robe. Zato je polica osiguranja redovito predviđena bankovnim akreditivnim nalogom. ${ }^{16}$

Međunarodno poslovanje prati sklapanje brojnih ugovora. Pri tome središnju ulogu ima ugovor o međunarodnoj prodaji robe. Ispunjenje ugovora o prodaji robe redovito prate još najmanje dva ugovora: ugovor o prijevozu robe i ugovor o osiguranju robe za vrijeme prijevoza. Iznimno se u suvremenim uvjetima roba prodaje i kupuje na način ,iz ruke u ruku“. Međunarodnu trgovinu obilježavaju izvozno-uvozni poslovi, na temelju kojih se roba iz jedne države izvozi u drugu ili se roba iz jedne države uvozi u drugu. ${ }^{17}$ Te se kupoprodaje realiziraju sklapanjem ugovora o prijevozu robe. Temeljna je dužnost prodavatelja da predmet kupoprodaje - robu isporuči kupcu u ugovorenom roku i u ugovorenom mjestu. Na taj se način, ugovor o prijevozu robe javlja u gospodarskoj funkciji robnog prometa. Sklapanjem ugovora o osiguranju robe za vrijeme prijevoza, nositelj interesa na robi zaštićuje svoj ekonomski interes od mogućnosti da roba propadne ili se ošteti zbog ostvarenja nekog transportnog rizika.

Osim tih ugovora, realizaciji jedne međunarodne prodaje pridonosi i sklapanje brojnih drugih ugovora, kao što su ugovor o zastupanju, špediciji, lučkom slagačkom poslu, skladištenju robe, kontroli kvalitete i kvantitete i dr. Premda su svi ti ugovori u funkciji realizacije jednog te istog ugovora o prodaji robe, oni su potpuno samostalni i međusobno odvojeni pravni poslovi. Te poslove najčešće prate i razni ugovorni odnosi s bankama koje kreditno financiraju nabavu robe ili se preko njih obavlja plaćanje kupoprodajne cijene. Taj je koncept u suvremenoj praksi uobičajen i općeprihvaćen. Na taj se način kod svakog izvozno-uvoznog posla redovito javljaju stranke iz ugovora o kupoprodaji (prodavatelj i ku-

14 O prijenosu police osiguranja opširnije Pavić, Drago, Prijenos ugovora o osiguranju, Hrvatska pravna revija, br. 3/2005., 2005.

15 Hobbs, Jane, Insurance of goods intransit, u Insurance Desputes, 2. ed., LLP, London, 2003. V. Pavić, Drago, Pomorsko osiguranje, Pravo i praksa, op. cit., str. 281.

16 O ulozi teretnice u bankarskom poslovanju opširnije u Todd, Paul, Bills of lading and bankers' documentarycredits, LLP, London, 1998. Opširnije o „,̌istoj teretnici“ i garantnom pismu u akreditivnom poslovanju v. Bendeković, Jadranka; Aržek, Zvonimir, Transport i osiguranje, Mikrorad, Ekonomski fakultet, Zagreb, 2008., str. 171.

17 Opširnije Pavić, Drago, Pomorsko osiguranje, Knjiga prva, CROATIA, Zagreb, 1986., str. 313. 
pac), koje snose komercijalni rizik posla; prijevoznik, koji kao nositelj prijevoznog pothvata odgovara za njegovo uredno izvršenje; osiguratelj robe, koji pruža zaštitu protiv ugovorenih transportnih rizika; banke, koje financijski prate čitavu transakciju preuzimajući na sebe rizik svoga poslovanja. ${ }^{18}$

Osnovni je izvor prava za ugovore o međunarodnoj prodaji Konvencija UN o međunarodnoj prodaji robe, 1980. (u nastavku i Bečka konvencija). ${ }^{19}$ Ta je konvencija danas širokoprihvaćena u svijetu, a ratificirala ju je i Republika Hrvatska. ${ }^{20}$ Odredbe te konvencije dispozitivne su pravne naravi pa je strankama ostavljena mogućnost da pojedina pitanja urede i drukčije, nego li je to predviđeno Konvencijom. Stranke mogu isključiti njenu primjenu ili pojedina pitanja urediti drukčije. U poslovnoj praksi ta se mogućnost široko koristi, pa stranke najvažnija pitanja iz ugovornog odnosa najčešće uređuju ugovornim odredbama. Takva su pitanja primjerice, mjesto isporuke, vrijeme isporuke, prijelaz rizika, uvjeti plaćanja, uvjeti osiguranja, plaćanje carine i dr. Sudionici robnog prometa za tu se svrhu često služe tipskim ugovorima i standardnim ugovornim klauzulama i pravilima. Za pravno uređenje međunarodne trgovine važna su i pravila Međunarodne trgovačke komore (MTK), sa sjedištem u Parizu (International Chamber of Commerce, ICC). ${ }^{21}$ Među tim pravilima posebno su značajna INCOTERMS pravila ${ }^{22}$ (International Commercial Terms, 2010.) i Jedinstvena pravila i običaji za dokumentarne akreditive (ICC Uniform Customs and Practice for Documentary Credits, 2007.).

\section{EKONOMSKO-PRAVNA POTREBA ZA OSIGURANJEM ROBE U TRANSPORTU}

\subsection{Upravljanje rizicima u međunarodnoj trgovini putem kargo osiguranja}

Sudionici međunarodnog robnog prometa izloženi su brojnim rizicima koji ugrožavaju uspješnost njihova poslovanja. Rizici mogu biti različite naravi. Najveća su opasnost za sigurnost robe transportni rizici, tj. opasnost da se roba za vrijeme transportnog procesa

19 Konvencija je donesena na diplomatskoj konferenciji u Beču 1980. godine pa se naziva i Bečka konvencija. Tu je konvenciju ratificirao velik broj zemalja, među ostalima i Republika Hrvatska, pa danas znači uspjeli pokušaj izjednačenja prava međunarodne prodaje. Za donošenje te konvencije zaslužna je Komisija UN za pravo međunarodne trgovine - UNCITRAL.

20 Tekst te konvencije s prijevodom na hrvatski jezik v. u Gorenc, Vilim, Schwank, Friedrich, Slakoper, Zvonimir, Međunarodna pravila za kupoprodaju, plaćanja i arbitraže, RRif, Zagreb, 1996.

${ }_{21}$ Međunarodna trgovačka komora (International Chamber of Commerce) utemeljena je 1919. Njen je temeljni zadatak da pomaže razvoju svjetskog gospodarstva promicanjem robne trgovine i investicija, širenjem tržišta za robu i usluge i slobodnom tijeku kapitala. U njenom okviru djeluje i institucionalna arbitraža od 1923. (ICC - International Court of Arbitration).

22 Incoterms pravila međunarodna su pravila za tumačenje trgovinskih termina koje je izradila Međunarodna trgovačka komora 1936. godine. Revidiraju se sukladno potrebama prakse te su 2010. godine Incoterms pravila posljednji put revidirana. Pojedinim terminom točno je određeno koje sve troškove s dopremom robe snosi prodavatelj, a koje kupac te u kojem trenutku rizik za slučajnu propast ili oštećenje stvari prelazi s prodavatelja na kupca. Za pregled Incoterms pravila v. Euro Star, Incoterms pariteti, internetski izvor: http://www.eurostar.hr/incoterms-pariteti-spedicija-rijeka-intrastat-carinjenje/ (30. 5. 2018.). 
fizički ošteti ili propadne zbog djelovanja nekog izvanrednog uzroka - transportnog rizika. To može rezultirati značajnim financijskim gubicima, koji mogu ugroziti čak i gospodarski opstanak pojedinog sudionika robnog prometa. Osim financijskih gubitaka nastalih zbog fizičkog oštećenja ili gubitka robe, moguće su i brojne posljedične štete, kao što su: poslovni financijski gubici, troškovi u vezi s oštećenom robom (popravci, prebiranje, prepakiranje i sl.), gubitak tržišta, gubitak poslovnog ugleda (eng. goodwill), posljedične štete zbog zakašnjenja, dužnost plaćanja penala zbog zakašnjenja i dr. Većinu od tih rizika moguće je izbjeći sklapanjem ugovora o osiguranju robe $u$ transportu s odgovarajućim izborom pokrića $i$ visinom osigurane svote. Zbog tih se razloga u literaturi naglašava „da bi bilo nepojmljivo da se vrijedna roba prevozi, a da nije osigurana." ${ }^{23} \mathrm{U}$ knjizi Handbook to Marine Insurance, Victora Dovera nalazimo ovo mišljenje: „Bilo bi pretjerano reći da se međunarodna trgovina ne bi mogla odvijati bez pomorskog osiguranja, ali nepostojanje toga osiguranja pričinilo bi značajne smetnje u odvijanju trgovačkih aktivnosti.“24 Potrebu za provođenjem osiguranja robe potvrđuju i brojni drugi razlozi. Teško je i zamisliti slučaj da jedna banka financira kupnju neke robe, a da se pritom ne osigura da će stranka provesti odgovarajuće osiguranje te robe za vrijeme prijevoza. Poseban slučaj imamo u spašavanju robe ili zajedničke havarije (general average). ${ }^{25}$ Prema pomorskom pravu spašavanja, u takvim slučajevima spašavatelj ima pomorsko založno pravo (privilegij) na spašenoj imovini dok mu se ne pruži jamstvo za plaćanje nagrade za spašavanje, što znači da može zadržati teret u svom posjedu. ${ }^{26}$ Nagrade za spašavanje i štete zajedničke havarije redovito su štete pokrivene osiguranjem robe pa osiguratelji robe spremno pružaju osiguranicima pisano jamstvo da će razmjerno vrijednosti osigurane imovine snositi dio nagrade za spašavanje ili doprinos u zajedničku havariju nakon što se sačini diobna osnova od strane ovlaštenog likvidatora (eng. average adjuster).

Provođenje osiguranja robe pruža gospodarstvenicima još jednu pogodnost. Ona se ogleda u tome što u tom osiguranju postoje vrlo široke mogućnosti da se pokriće osiguranjem prilagodi zahtjevima i potrebama ugovaratelja osiguranja i specifičnostima pojedinih roba. Roba se može osigurati samo od osnovnih rizika (prometna nesreća, viša sila i sl.), ali i od „svih rizika“ (u smislu izvanrednih vanjskih događaja) s mogućnošću osiguranja brojnih dopunskih rizika, koji nisu obuhvaćeni pojmom „svi rizici“. Izborom odgovarajućeg tipa osiguranja može se uspješno upravljati rizicima te ostvariti priželjkivanu komercijalnu i financijsku sigurnost. Ta sigurnost čini nepotrebnim stvaranje posebnih fondova gospodarstvenika (osiguranika) za pokriće financijskih gubitaka u poslovanju zbog ostvarenja transportnih rizika. Sve to potiče gospodarstvenike na provođenje osiguranja, što u konačnici pridonosi razvoju međunarodne trgovine općenito.

Zbog takve uloge osiguranja, poželjno je da gospodarstvenici prije sklapanja ugovora o osiguranju, provedu odgovarajuće predradnje i metode upravljanja rizikom o čemu ovisi

23 Vishwanath, K. S., Insuring Cargoes, Witherbys Insurance, Edinburg, 2010., str. 3. O pojmu i funkciji osiguranja v. Bendeković, Jadranka; Aržek, Zvonimir, Transport i osiguranje, op. cit., str. 328. - 329.

24 Dover, Victor, A Handbook to Marine Insurance, op. cit., str. 90. Opširnije o gospodarskom značenju kargo osiguranja v. Pavić, Drago, Pomorsko osiguranje, Pravo i praksa, op. cit., str. 32. - 33.

25 V. Institute Cargo Clauses (A), (B), (C) 1982., 2009., klauzula 2. Zajednička havarija (General Average).

26 O pravu spašavanja i pravu zajedničke havarije opširnije: Kennedy and Rose, The Law of Salvage, Sweet and Maxwell, London, 2002.; Petrinović, Ranka, Plančić, Bisera, Hrvatsko pravo spašavanja u uvjetima europskih integracija, Poredbeno pomorsko pravo, br. 161/2007., 2007.; Pavić, Drago, Pomorsko imovinsko pravo, Književni krug, Split, 2006.; Rose, E. D., General Average, Law and Practice, LLP, London, 2005. 
uspješnost toga postupka. Pri donošenju odluke o osiguranju robe, osiguranik mora najprije ocijeniti svoj osigurljiv interes u odnosu na robu - predmet osiguranja, vrijednost toga interesa radi određivanja osigurane svote i uzeti u obzir brojne faktore koji utječu na rizičnost prijevoza i cijenu osiguranja. Među njima su: kategorije rizika kojima je izložena roba, vrste rizika i šteta koji se žele osigurati, vrsta tipiziranog pokrića, vrsta robe i osjetljivost robe u odnosu na neke rizike, vrsta prometa i prijevoznog sredstva, prevozi li se roba na palubi broda ili ne, putovanje, prekrcaj robe, vrsta pakiranja, prevozi li se roba u kontejnerima ili drugim napravama za objedinjavanje tereta, trajanje osiguranja, koje dopunske rizike osigurati, treba li osim transportnih rizika osigurati i ratne rizike, rizike štrajka i dr.

Pri sklapanju osiguranja treba posebno voditi računa o primjeni načela dobre vjere (eng. utmost good faith), kao jednog o temeljnih načela ugovora o pomorskom osiguranju, što znači da je ugovaratelj osiguranja dužan pri sklapanju ugovora potpuno i istinito informirati osiguratelja o svim okolnostima koje su važne za donošenje odluke o sklapanju ugovora i ocjenu težine rizika. Propust ugovaratelja osiguranja u tom pogledu može utjecati na pravnu valjanost posla (v. Pomorski zakonik, čl. 689., čl. 690.).

\subsection{Interes stranaka iz ugovora o prodaji za osiguranje robe}

Stranke iz ugovora o međunarodnoj prodaji po naravi su stvari zainteresirane da roba (objekt prodaje) bude na osiguravajući način osigurana za vrijeme prijevoza od transportnih rizika. U suprotnome, prijeti im opasnost da pretrpe materijalnu štetu u slučaju gubitka ili oštećenja robe. U takvom slučaju, interes stranaka za osiguranje pravno je opravdan $i$ materijalne je naravi pa udovoljava svim zakonskim uvjetima da bi bio „osigurljiv“ (v. čl. 685. st. 1.). ${ }^{27}$ Prema pravu osiguranja, postojanje interesa bitan je uvjet da bi neka osoba mogla steći svojstvo osiguranika (korisnika osiguranja). Pomorski zakonik izrijekom naglašava da osiguranik može biti samo osoba koja ima, ili koja može očekivati da će imati opravdani materijalni interes da ne nastupi osigurani slučaj (v. čl. 685. st. 1.). Odredba Pomorskog zakonika o osigurljivom interesu je prisilne pravne naravi odnosno strankama nije dana mogućnost da ugovore drugačije. ${ }^{28}$ Postojanje interesa za osiguranje utvrđuje se prema pravilu obveznog prava o prijelazu rizika prema kojem interes za osiguranje ima ona stranka iz ugovora o prodaji koja je za vrijeme transporta nositelj rizika za slučajnu propast ili oštećenje robe. Pod pojmom ,rizik“ podrazumijevaju se moguće promjene na robi fizičke naravi, koje nastaju bez krivnje ugovornih strana, a mogu umanjiti ili potpuno ukloniti materijalna svojstva stvari, a time i njenu vrijednost. Značenje pojma „rizik“ ne proteže se i na poslovni rizik već su pod tim pojmom obuhvaćene isključivo fizičke promjene na stvari poput raznih oštećenja, manjkova, zatim krađa ili gubitak stvari i slično. ${ }^{29}$

Obilježje je međunarodne prodaje da se pri ispunjenju ugovora o prodaji mijenjaju nositelji rizika. Rizik s prodavatelja prelazi na kupca. Kako do rizika dolazi bez krivnje ugovornih strana, što znači da niti ne postoji njihova odgovornost za štetu pa se kao osnovno

\footnotetext{
27 Prema Pomorskom zakoniku, interes da bi bio podoban za osiguranje potrebno je da je: a) opravdan odnosno pravno dopušten i b) materijalan (čl. 685. st. 1.).

28 Opširnije Pavić, Drago, Interes osiguranja, Zbornik Pravnog fakulteta u Splitu, br. 79/2005., 2005., str. 433.

29 Tako i Mlikotin-Tomić, Deša, Pravo međunarodne trgovine, Školska knjiga, Zagreb, 1999., str. 163.
} 
pravno pitanje javlja koja će stranka snositi štetne posljedice nastupa rizika, hoće li to biti prodavatelj ili kupac. Pravilo o prijelazu rizika utvrđuje u kojem trenutku u fazi ispunjenja ugovora, rizik za slučajnu propast ili oštećenje stvari prelazi s prodavatelja na kupca, a time ujedno prelazi i interes za osiguranje stvari za vrijeme prijevoza. Na primjer, kod kupoprodaje FAS (Free Alongside Ship - Franko uz bok broda, Incoterms, 2010.), prodavatelj je isporučio robu kupcu kada je roba u ukrcajnoj luci smještena uz bok broda. Predajom robe, rizik za gubitak ili oštećenje robe prelazi s prodavatelja na kupca. Do trenutka polaganja robe uz bok broda, rizik je na prodavatelju i on ima interes za osiguranje, a od tog trenutka rizik je na kupcu, što znači da kupac ima interes osigurati robu za vrijeme prijevoza.

Posebno, u odnosima iz međunarodne kupoprodaje čest je slučaj da se roba dok prijevoz još traje kupuje i prodaje čime interes za osiguranje prelazi na novog kupca robe. U slučaju da je već sklopljeno osiguranje tada prava iz ugovora treba prenijeti na novog kupca robe, što se uobičajeno čini prijenosom police osiguranja. Polica osiguranja može se prenositi nebrojeno puta. Ne postoje pravna ograničenja u broju prijenosa police osiguranja, međutim može se javiti problem dokazivanja koja je osoba, u lancu više njih, u trenutku nastanka štete bila nositelj rizika odnosno koja od njih ima pravo postaviti odštetni zahtjev osiguratelju. Osnovno načelo prava pomorskog osiguranja kaže da „osiguranik može tražiti naknadu za štetu samo ako je imao interes na osiguranom predmetu u trenutku nastupa osiguranog slučaja. “30 U međunarodnoj kupoprodaji primjena tog načela nije uvijek primjerena jer do štete na teretu može doći i prije trenutka prijelaza rizika, a bez da je osiguranik to znao odnosno bez da je to mogao znati. To znači da bi pri strogoj primjeni navedenog načela, osiguranik (kupac) bio onemogućen naplatiti štetu iz osiguranja jer u trenutku nastupa štete nije imao interes na osiguranom predmetu. Takav slučaj bi se dogodio kada bi na primjer, bila ugovorena kupoprodaja FOB (Free on Board - Franko brod) ili CFR (Cost and Freight - Trošak $i$ vozarina) koje imaju isti trenutak prijelaza rizika, a to je ukrcaj robe na brod. U slučaju da je bez znanja osiguranika (kupca robe), šteta na robi nastala na nekoj kopnenoj točki, na mjestu gdje čeka na ukrcaj, osiguranik se ne bi uspio naplatiti iz osiguranja kojeg je sklopio jer nije bio nositelj rizika u trenutku nastanka štete. ${ }^{31}$ Za takve situacije pravo pomorskog osiguranja poznaje posebno pravilo kojim uvažava specifičnost pomorske kupoprodaje. Prema Pomorskom zakoniku, naknadu za štetu pokrivenu osiguranjem osiguranik može tražiti ako je imao interes na osiguranom predmetu u trenutku nastupanja osiguranog slučaja, ali i ako je stekao interes nakon toga (čl. 685. st. 2.). Naplata šteta nastalih prije sklapanja ugovora o osiguranju, prema Pomorskom zakoniku dana je uz uvjet da u trenutku sklapanja ugovora, ugovaratelj osiguranja i osiguranik nisu znali, niti su morali znati da je već nastupio osigurani slučaj (čl. 707.). Poredbenopravni sustavi sadrže slična pravna rješenja. Za englesko pravo pomorskog osiguranja karakteristična je primjena načela „lost or not lost". Ako je osiguranje sklopljeno prema načelu ,lost or not lost“, ${ }^{32}$ prema Marine Insurance Act-u (1906.), osiguranik može naplatiti štetu premda nije stekao interes prije nastanka štete, osim ako mu je činjenica nastanka štete bilo poznata u trenutku sklapanja ugovora o osiguranju, a osiguratelju nije (čl. 6. st. 1.). U engleskim standardnim uvjetima za osiguranje robe nalazi se istoimena klauzula prema kojoj je osiguratelj obvezan

\footnotetext{
30 V. čl. 6. st. 1. MIA, 1906; čl. 685. st. 5.2. PZ; Institute Cargo Clauses (A).

31 Usp. Dunt, John, International Cargo Insurance, Informa, London, 2012., str. 521. O osigurljivom interesu u odnosima iz kupoprodaje v. Pavić, Drago, Pomorsko osiguranje, Pravo i praksa, op. cit., str. 281. - 282. O klauzuli Lost or not Lost v. Pavić, Drago, Pomorsko osiguranje, Pravo i praksa, op. cit., str. 98. - 99.
} 
i za štete koje su nastale prije sklapanja ugovora pod uvjetom da to osiguraniku nije bilo poznato (I.C.C. (A), klauzula 11.2.).

Pravila o prijelazu rizika poredbenopravnih sustava dispozitivne su pravne naravi, stoga stranke mogu ugovoriti i drugačije. Stranke će svoj kupoprodajni odnos posebno urediti ugovornim pogodbama ili će ugovoriti primjenu jednog od standardnih trgovačkih termina iz zbirke Incoterms. Svakim pojedinim terminom su definirana najvažnija pitanja iz ugovora, posebno pitanje isporuke robe, prijelaza rizika, dužnosti podmirenja pojedinih troškova te izvršenja niza radnji u vezi s prijevozom, osiguranjem, uvozno-izvoznim i carinskim formalnostima. ${ }^{33}$

\subsection{Sklapanje ugovora o osiguranju robe kao ugovorna obveza prodavatelja}

Kako je već naglašeno, s predajom robe prelazi s prodavatelja na kupca rizik za slučajnu propast ili oštećenje stvari, a time i interes za osiguranje stvari za vrijeme prijevoza. Prodavatelj i kupac samostalno odlučuju, svaki za svoju dionicu puta na kojoj su nositelji rizika hoće li sklopiti osiguranje, zatim kod kojeg osiguratelja te prema kojim uvjetima osiguranja. Posao osiguranja strankama pruža ekonomsku zaštitu od različitih opasnosti koje mogu ugroziti njihovu imovinu. Kada bi tijekom prijevoza došlo do oštećenja stvari, a ne postoji odgovornost niti jedne ugovorne strane, stranka koja je nositelj rizika u tom trenutku pretrpjela bi materijalni gubitak ako se nije prije toga valjano zaštitila putem osiguranja.

Opće je načelo da niti prodavatelja niti kupca ne tereti dužnost osiguranja robe za vrijeme prijevoza, kao ni obveza sklapanja osiguranja u korist druge stranke, osim ako se nisu na to obvezale ugovorom. Iznimno, Incoterms termini CIF - „Cost, Insurance and Freight“ (Trošak, osiguranje i vozarina, 2010.) i CIP - „Carriage and Insurance Paid to“ (Vozarina i osiguranje plaćeni do..., 2010.) predviđaju za prodavatelja obvezu sklapanja ugovora o osiguranju robe u korist kupca.

Prema terminu CIF, rizik za gubitak ili oštećenje robe prelazi s prodavatelja na kupca ukrcajem robe na brod, dok prema CIP terminu, rizik prelazi u trenutku predaje robe prvom prijevozniku. $\mathrm{U}$ obje kupoprodaje osigurljiv interes za vrijeme prijevoza robe ima kupac. ${ }^{34}$ Unatoč tome što za vrijeme transporta interes za osiguranjem ima kupac, ovim terminima, prodavatelj preuzima ugovornu obvezu da će sklopiti ugovor o osiguranju u korist kupca čime on praktično osigurava interes kupca. Međutim, kako prodavatelj nije nositelj interesa za vrijeme transporta, tada on niti ne može naknaditi štetu nastalu za vrijeme prijevoza. Naknadu iz osiguranja može potraživati samo osoba koja ima interes na robi u vrijeme nastanka štete. ${ }^{35}$ Prodavatelj mora osigurati da kupac ili neka druga osoba koja ima interes

33 Opširnije o osigurljivom interesu u primjeni Incoterms pravila v. Lovrić, Ivana, Osigurljiv interes prema novim Incoterms pravilima, Zbornik Pravnog fakulteta u Splitu, br. 1/2017., 2017., str. 301. - 318.

$34 \quad$ V. Jurić, Dionis; Mihić, Jelena, Prijelaz rizika s prodavatelja na kupca kod ugovora o međunarodnoj kupoprodaji s osvrtom na INCOTERMS 2010., Zbornik Pravnog fakulteta Sveučilišta u Rijeci, br. 1, 2012., str. 355. -387.

35 Prema Institute Cargo Clauses (A), (B) i (C) iz 2009., osiguranje počinje kada osigurani predmet bude prvi put pomaknut u skladištu radi neposrednog ukrcaja u prijevozno sredstvo u svrhu početka prijevoza. Osiguranje se nastavlja za vrijeme uobičajenog tijeka prijevoza i završava pošto završi iskrcavanje s prijevoznog sredstva u krajnjem skladištu u mjestu predviđenom ugovorom (klauzula 8.1.1., Transit Clause). 
na robi može izravno od osiguratelja potraživati naknadu štete, što praktično znači da prodavatelj mora prenijeti svoja prava iz police osiguranja na kupca. Novi ovlaštenik iz police je zakoniti imatelj originala police, koji dokaže da je u trenutku nastanka štete imao interes u odnosu na osigurani predmet.

Prema terminima CIF i CIP prodavatelj je dužan osigurati robu s minimalnim pokrićem. To je sukladno općem pravilu Incoterms pravila da za stranke predviđaju minimalne obveze, kao i činjenice da se osiguranje zapravo sklapa za račun kupca. Kao minimalno pokriće uzima se pokriće osnovnih rizika kako je predviđeno klauzulama I.C.C.(C), LMA/ IUA $^{36}$ ili nekim drugim sličnim uvjetima. To osiguranje ne pokriva brojne rizike i štete pa se može javiti potreba za širim pokrićem. Posebice će to biti slučaj kada se roba prodaje dok prijevoz još traje. Zbog tih je razloga predviđeno da je prodavatelj dužan, ako to zatraži kupac i pruži mu potrebne informacije, osigurati robu o trošku kupca prema uvjetima koji pružaju dodatno osiguranje, npr. prema I.C.C. (A), osiguranju „svih rizika“ ili osigurati robu od ratnih rizika i rizika štrajka. Obveza osiguranja prema širim uvjetima od ,minimalnih" može biti predviđena i akreditivnim nalogom (opširnije, u nastavku). Kupac može osiguranje dodatnih rizika provesti i samostalno.

Prodavatelj je dužan osigurati robu kod osiguratelja dobrog glasa, minimalno na vrijednost koja je predviđena ugovorom o prodaji (vrijednost robe, vrijednost premije osiguranja plus vozarina), uvećanu za $10 \%$ (tj. 110 posto ugovorne cijene). ${ }^{37}$ Roba se mora osigurati $\mathrm{u}$ valuti ugovora.

\section{ULOGA POMORSKE POLICE OSIGURANJA U MEĐUNARODNOJ TRGOVINI}

\subsection{Pravna obilježja pomorske police osiguranja}

Posebnu i nezamjenjivu ulogu u odvijanju međunarodne trgovine ima pomorska polica osiguranja (engl. Marine Insurance Policy). U osiguranju robe naziva se pomorska kargo polica osiguranja (engl. Marine Cargo Policy). U osiguranju robe, osim pomorske police, primjenjuju se i drugi oblici isprava o osiguranju, kao što su certifikat osiguranja, potvrda o osiguranju i dr., ali je pomorska polica najvažnija i praktično najčešće primjenjivana isprava o osiguranju u odnosima iz međunarodne trgovine. Uporaba pomorske police u tim odnosima, zbog njenih specifičnih pravnih svojstava, dodatno potvrđuje važnost pomorskog osiguranja za odvijanje međunarodnog robnog prometa. Pomorska polica osiguranja pravno

$36 \quad$ Institutske su klauzule zbirke ugovornih odredbi (uvjeta osiguranja) koje je publicirao Institute of London Underwriters (ILU, Asocijacija londonskih pomorskih osiguratelja). Asocijacija je pod tim imenom djelovala sve do 1999. godine, kada se spojila s asocijacijom LIMRA te od kada djeluje pod nazivom International Underwriting Association (IUA). International Underwriting Association zajedno s Lloyd's Market Association (LMA) predstavlja osnovu londonskog tržišta osiguranja. Zajedničko tijelo tih dviju asocijacija tzv. Joint Cargo Committee djeluje danas na reviziji starih klauzula i izradi novih jedinstvenih standardnih uvjeta osiguranja koje se bezrezervno primjenjuju i izvan engleskog tržišta osiguranja.

Pregled institutskih klauzula v. International Underwriting Association, IUA Clauses, internetski izvor: http://www.iuaclauses.co.uk/site/cms/contentChapterView.asp?chapter=21.

37 U kupoprodajnoj cijeni robe obuhvaćen je osim cijene robe i trošak vozarine i osiguranja, tzv. CIF vrijednost. 
je pisani dokaz o postojanju i sadržaju ugovora o osiguranju. U literaturi se definira kao „,isprava o osiguranju, potpisana od osiguratelja kojom se potvrđuje postojanje ugovora i u osnovi određuje njegov sadržaj“. ${ }^{38}$ Oblik pomorske police osiguranja nije propisan. Danas se u praksi ustalila primjena police koja se, po uzoru na novu englesku policu, kolokvijalno naziva „nova pomorska polica“ (engl. New Marine Policy Form). Time se želi napraviti razlika između te police i povijesno važne standardne engleske S.G. police (engl. Lloyd's S.G. Policy Form). ${ }^{39}$ U poslovnoj praksi svaki osiguratelj posluje sa svojim obrascem pomorske police. Njihov se sadržaj u osnovi ne razlikuje.

Pomorskom policom sadržajno se uređuje odnos između korisnika osiguranja i osiguratelja. Tipski obrazac pomorske police, kojom se osigurava roba u međunarodnoj prodaji, redovito sadrži podatke o strankama ugovora o osiguranju, osiguranom predmetu, trajanju osiguranja ili osiguranoj relaciji, vrsti prijevoznog sredstva - imenu broda, osiguranoj vrijednosti koja među strankama može biti i sporazumno utvrđena (ugovorena vrijednost; engl. agreedvalue), ugovoreni standardni uvjeti osiguranja, kao i posebne ugovorne odredbe. Iz toga proizlazi da se iz pomorske police mogu utvrditi svi elementi ugovora. Posebice su važne odredbe standardnih uvjeta osiguranja i posebnih ugovornih odredbi za poslove upravljanja rizicima. S razlogom se zbog toga naglašava da su ,standardne klauzule u policama osiguranja najizrazitiji primjer uspješnih pokušaja dijela poslovnog poduzetništva pri izboru i upravljanju rizicima obuhvaćenih ugovorom. ${ }^{\text {“40 }}$

Osim što se policom osiguranja uređuje odnos stranaka iz ugovora o osiguranju, njezina pravna svojstva osiguravaju joj izvanredno važnu ulogu u odvijanju međunarodne trgovine. Najvažnije takvo pravno svojstvo jest svojstvo prenosivosti. Prijenosom police osiguranja prenose se prava iz police na treću osobu, konkretno na kupca robe. Zbog toga se može reći da je mogućnost prijenosa police osiguranja kamen temeljac njene uloge u odvijanju međunarodne trgovine. Najvažnije je da se time prenosi pravo na naknadu štete iz osiguranja. ${ }^{41}$ Prijenos police osiguranja obavlja se indosiranjem police ili na drugi odgovarajući način.

Svojstvo prenosivosti pomorske police povijesno je utemeljeno upravo u međunarodnom osiguranju robe. Nastalo je prije svega iz poslovne potrebe da se prava iz ugovora o osiguranju robe, kojeg je sklopio prodavatelj mogu prenijeti na kupca robe. Osim toga, za međunarodnu trgovinu je karakteristično da se roba za vrijeme prijevoza kupuje i prodaje. Time se mijenjaju nositelji rizika da se roba slučajno ne ošteti ili propadne dok prijevoz još traje, što znači da se mijenjaju i nositelji interesa za osiguranje. Zbog toga je izvanredno važno da se prava iz osiguranja mogu prenositi s jednog nositelja prava na robi, na novog vlasnika robe. To vrijedi i za prava iz ugovora o prijevozu robe gdje se kao instrument prijenosa prava javlja pomorska teretnica s pravnim svojstvom prenosivog vrijednosnog papira (engl. document of title). Prijenosom pomorske teretnice prenose se i prava iz ugovora na treću osobu. Tada je brodar dužan predati teret osobi koja se na odredištu legitimira kao

38 Pavić, Drago, Pomorsko osiguranje, Pravo i praksa, op. cit., str. 133.

39 O pomorskoj polici opširnije u Tomašić, Veljko, Pravna priroda pomorske izvozne police, Beograd, 1967.

40 Kessler, Friedrich, Contracts of Adhesion, Some Thoughts About Freedom of Contracts, Faculty Scholarship Series, Paper 2731., Yale Law School, 1943.

${ }_{41}$ O pravnim učincima prijenosa pomorske police osiguranja v. Pavić, Drago, ibidem, str. 146. i d.; Pavić, Drago, Prijenos police osiguranja, Svijet osiguranja, br. 1/2007., 2007., str. 44. 
zakoniti posjednik teretnice, tj. osobi koja može dokazati da je na posjedovanje teretnice formalno legitimirana. ${ }^{42}$

Pomorska polica osiguranja, kao i pomorska teretnica, zahvaljujući svojstvu prenosivosti cirkulira u prometu zajedno s ostalim robnim dokumentima. Naglašava se da je na svojstvu prenosivosti police utemeljen čitav suvremeni sustav osiguranja u međunarodnoj prodaji robe. „Danas je to obilježje pomorske police utvrđeno nacionalnim zakonima, međunarodnim autonomnim regulativama za međunarodnu trgovinu (Incoterms pravilima $i$ Jedinstvenim pravilima i običajima za dokumentarne akreditive koje je publicirala Međunarodna trgovačka komora - MTK), sudskim presudama i priznatom poslovnom praksom. ${ }^{643}$

\subsection{Uloga pomorske police u dokumentarnoj naplati}

Pomorska polica osiguranja ima važnu ulogu i u funkcioniranju međunarodnog dokumentarnog akreditiva. Ta se uloga temelji na činjenici da je pomorska polica osiguranja pisani dokaz o sklopljenom ugovoru i o njegovu sadržaju. Zbog toga je redovito predviđena akreditivnim nalogom kod onih oblika kupoprodaje kod kojih je obveza sklapanja ugovora o osiguranju robe za vrijeme prijevoza na prodavatelju (CIF, CIP). U tim je kupoprodajama neizbježno da se među akreditivnim ispravama javlja i isprava o osiguranju. Time se dokazuje da je prodavatelj ispunio svoju ugovornu obvezu ugovaranja osiguranja, pa je normalno da kupac navođenjem te isprave $\mathrm{u}$ akreditivnom nalogu uvjetuje isplatu akreditivnog iznosa (cijene robe) ispunjenjem i te ugovorne obveze. Osim toga, i u drugim oblicima kupoprodaja, kod kojih prodavatelj nema interes za osiguranje robe za vrijeme prijevoza (npr. kupoprodaja Ex Works), stranke mogu posebno ugovoriti da će prodavatelj provesti osiguranje u ime i za račun kupca, kao njegov opunomoćenik, pa kupac u takvom slučaju opravdano među akreditivnim ispravama može propisati i ispravu o osiguranju. To je razlog što Jedinstvena pravila i običaji za dokumentarne akreditive MTK (Uniform Customs and Practice for Documentary Credits) iz 2007. godine sadrže i posebne odredbe o ispravama o osiguranju (čl. 28. Insurance document and coverage). Akreditivno prihvatljive su samo one isprave o osiguranju koje su izdane i potpisane od strane osiguravajućeg društva, osiguratelja (engl. underwriter) ili njihovih zastupnika ili opunomoćenika (čl. 28.a). Kao primjeri se navode: polica osiguranja (engl. insurance policy), certifikat o osiguranju (engl. insurance certificate) ili izjava iz ugovora o otvorenom pokriću (engl. declaration under an opencover). Ako je u akreditivnom nalogu označen neki točno određeni oblik isprave o osiguranju, banka će prihvatiti policu osiguranja ili certifikat samo u tom obliku. Umjesto certifikata ili izjave iz otvorenog pokrića, prema posebnoj odredbi Jedinstvenih pravila i običaja za dokumentarne akreditive, bit će prihvatljiva polica osiguranja (čl. 28.d). Zastupnici ili opunomoćenici moraju djelovati u ime ili za račun osiguratelja (for or on behalf of the insurance company or underwriter; čl. 28.a, st. 2.). Potvrde o pokriću (engl. cover notes) koje izdaju brokeri nisu prihvatljive u akreditivnom poslovanju (čl. 34.).

\footnotetext{
42 O prijenosu teretnice opširnije Grabovac, Ivo, Suvremeno hrvatsko pomorsko pravo i Pomorski zakonik, Književni krug, Split, 2005., str. 93.

43 Pavić, Drago, Prijenos police osiguranja, Svijet osiguranja, op. cit., str. 44.
} 
Kao i u prijašnjim verzijama, nova Jedinstvena pravila iz 2007. također sadržavaju odredbu o osiguranju ,svih rizika“. Prema toj odredbi, ako se u akreditivu zahtijeva osiguranje „svih rizika“ (engl. all risks), bit će prihvaćena svaka isprava o osiguranju koja sadrži bilo koju zabilježbu ili klauzulu „svi rizici“. Isprava o osiguranju bit će prihvaćena bez obzira na bilo koje rizike za koje se navodi da su isključeni iz osiguranja (čl. 28.h).

Jedinstvena pravila sadrže i posebnu odredbu o isključenjima iz osiguranja. Prema toj odredbi, isprava o osiguranju može upućivati na bilo kakvu klauzulu o isključenjima iz osiguranja (čl. 28. i). Takve odredbe sadrže svi standardni uvjeti za osiguranje robe pa čak i uvjeti za osiguranje „svih rizika“, primjerice Institute Cargo Clauses (A).

Nova Jedinstvena pravila i običaji za dokumentarne akreditive iz 2007. godine, kao i prijašnja, sadrže odredbu o franšizama. Prema toj odredbi, u ispravi o osiguranju može biti naznačeno da je pokriće podložno primjeni ugovorene franšize ili odbitne franšize, što znači da će takve isprave biti prihvatljive za banke (čl. 28.j).

\section{UGOVORNA SLOBODA U SKLAPANJU UGOVORA O OSIGURANJU ROBE}

Opće je načelo prava osiguranja poredbenopravnih sustava da stranke slobodno $\mathrm{u}$ zaštiti svojih interesa donose odluku o sklapanju ugovora o osiguranju i o njegovu sadržaju. Iznimka od toga općeg načela postoji samo u osiguranjima od odgovornosti. Opće je usvojeno da u nekim osiguranjima od odgovornosti postoji visok stupanj javnog interesa, koji opravdava ograničavanje slobode u sklapanju ugovora propisivanjem tih osiguranja kao obveznih. Takav interes postoji, primjerice, u propisivanju obveznih osiguranja u prometu (autoodgovornost), osiguranju odgovornosti za štete na prirodnom okolišu, posebice morskom, osiguranju odgovornosti za smrt i tjelesne ozljede putnika i dr. Na taj se način socijalizira rizik i osigurava zaštita šireg kruga ljudi i prirodnog okoliša.

Načelo slobode ugovaranja vrijedi i u međunarodnom osiguranju robe. Stranke iz ugovora o prodaji robe nisu zakonski dužne osigurati robu za vrijeme prijevoza, osim ako se nisu na to ugovorno obvezale. Takva dužnost ne tereti ni prijevoznika. Nije uobičajeno da prijevoznik osigurava robu koju je preuzeo na prijevoz. Ako se roba ošteti ili propadne za vrijeme prijevoza, prijevoznik će odgovarati korisniku prijevoza za naknadu štete prema propisima kojima je taj prijevoz uređen. Iz toga proizlazi njegov interes da osigura svoju odgovornost za tu robu. Sklapanjem ugovora o osiguranju svoje odgovornosti prijevoznik ne osigurava robu kao takvu, nego samo svoju odgovornost za robu primljenu na prijevoz. Otpremnik (špediter) isto tako nije dužan osigurati robu, ako se ugovorom nije na to obvezao. Ostaje, prema tome, da stranke iz ugovora o kupoprodaji sklapanjem ugovora o osiguranju robe za vrijeme prijevoza same zaštite svoj materijalni interes u slučaju da roba za vrijeme prijevoza propadne ili se ošteti. Posebno je važno naglasiti da stranke ne mogu računati da će potpuno nadoknaditi štetu od prijevoznika s naslova njegove odgovornosti za robu primjenu na prijevoz. To neće moći ni kada postoji osiguranje prijevoznika od odgovornosti za štete na teretu. U literaturi je to objašnjeno na ovaj način: Sklapanjem ugovora o osiguranju odgovornosti, prijevoznik osigurava svoju zakonsku odgovornost, a ne samu robu. Prijevoznik odgovara „od preuzimanja do predaje“, a roba je izložena opasnostima od početne do završne točke puta (najmanje „od skladišta do skladišta“"). Te se dvije relacije ne moraju 
poklapati. Osim toga, postoje opasnosti za koje prijevoznik zakonski ne odgovora, npr. za višu silu i tzv. Posebne opasnosti. Prijevoznik nikada ne odgovara za štete zbog unutrašnje mane ili prirodnog svojstva robe, a osiguranje pruža i takvu mogućnost. Osiguranje robe se sklapa na njenu tržišnu vrijednost, a prijevoznik odgovara po visini ograničeno, tj. do graničnog iznosa propisanog odgovarajućom konvencijom ili nacionalnim zakonom. U osiguranu vrijednost robe može se uključiti i stanoviti postotak na ime očekivane dobiti (obično $10 \%$ ), a to se kod odgovornosti ne uzima u obzir. Osiguranje robe pruža široku mogućnost izbora rizika, od „svih rizika“ do osiguranja samo osnovnih rizika o čemu ovisi i visina premije. ${ }^{44}$ Iz toga jasno proizlazi da neovisno o postojanju prijevoznikove odgovornosti za robu, ne prestaje potreba za osiguranjem robe u prijevozu.

Iz navedenoga se može zaključiti da stranke iz ugovora o međunarodnoj prodaji sklapanjem ugovora o osiguranju štite svoj vlastiti interes da ne pretrpe materijalni gubitak zato što je za vrijeme prijevoza došlo do oštećenja ili gubitka robe preuzete na prijevoz. S tim u vezi su i pojmovi interes osiguranja i osigurljivi interes.

Ugovorom o prodaji može se predvidjeti dužnost neke od stranaka da osigura robu. Tada stranke sklapanjem ugovora o osiguranju, predviđenog ugovorom o prodaji, ispunjavaju svoju ugovornu obvezu. Na primjer, terminom Incoterms, $2010 .{ }^{45} \mathrm{CIF}$ (Cost, Insurance and Freight - ugovorena odredišna luka) i terminom CIP (Carriage and Insurance Paid to... - ugovoreno odredišno mjesto) predviđena je dužnost prodavatelja da sklopi ugovor o osiguranju robe za vrijeme prijevoza (opširnije, u nastavku).

\section{ZAKONSKO OGRANIČENJE SLOBODE U IZBORU OSIGURATELJA}

Dok pri donošenju odluke o sklapanju ugovora o osiguranju u suvremenim uvjetima postoji opća sloboda, s iznimkom obveznih osiguranja od odgovornosti, takva opća sloboda ne postoji u svim pravnim sustavima kada je u pitanju izbor osiguratelja. U brojnim državama propisane su razne mjere kojima se ograničava sloboda u izboru osiguratelja kao i tržišta na kojem će se osiguranje provesti. Tim se mjerama nastoji zaštititi domaće tržište na način da se ekonomski učinci od provođenja kargo osiguranja usmjere u nacionalnu ekonomiju. Konačan cilj tih mjera je dvostruk: a) razvoj nacionalne industrije osiguranja, b) smanjenje izdataka u stranoj valuti za premiju osiguranja. ${ }^{46}$

Propisane restriktivne mjere, koje se mogu primjenjivati pojedinačno ili u kombinaciji više njih, uglavnom su ove:

- zabrana za prodavatelje da osiguraju izvoz u drugoj državi

- zabrana za kupce da osiguraju uvoz u drugoj državi

- zabrana za prodavatelje da izvoze robu po paritetu FOB

\footnotetext{
44 Opširnije: Radionov, Nikoleta, Odgovornost cestovnog prijevoznika za robu i poslovi osiguranja, Osiguranje, br. 12/1, 2009.; Pavić, Drago, Pomorsko osiguranje, Pravo i praksa, op. cit., str. 477.; Hobbs, Jane, Insurance of goods intransit u Insurance Disputes, op. cit., 2003.

$45 \quad$ INCOTERMS znači International Commercial Terms.

46 Prema Debattista, Charles, Incoterms in Practice, ICC Publication No. 505(E), Pariz, 1995., str. 93. Opširnije v. Pavić, Drago, Pomorsko osiguranje, Pravo i praksa, op. cit., str. 34.
} 
- zabrana za kupce da uvoze robu po paritetu CIF

- propisivanje visokih taksi za osiguranja plasirana u stranoj državi

- uvođenje uvoznih dozvola i kontrole financiranja uvoza, valutne restrikcije. ${ }^{47}$

Propisivanjem tih mjera nastoji se ostvariti da se osiguranje robe u izvozu i uvozu provodi na domaćem tržištu - kod domaćih osiguratelja. To se prije svega postiže ugovaranjem odgovarajućeg tipa kupoprodaje. Osnovno je pravilo u tom pogledu da se roba $u$ izvozu prodaje po paritetu CIF, a uvozi po paritetu FOB. Prodajom robe prema terminu CIF, stranom kupcu se osim robe ,prodaje“ i osiguranje i naplaćuje cijena prijevoza. Time se povećava devizni priljev u zemlji izvoznici. Slično tome, kupnjom robe po paritetu FOB stranom prodavatelju plaća se samo cijena robe, što znači da je devizni odljev najmanji. Sustav restriktivnih mjera primjenjuje se pretežito u zemljama u razvoju. U njegovoj primjeni javljaju se brojne teškoće, posebice zbog nekonkurentnosti i nedovoljnog kapaciteta domaćeg tržišta osiguranja te problema plaćanja šteta u stranim sredstvima plaćanja. Posebice se naglašava da sloboda u izboru osiguratelja (Freedom of Insurance) ${ }^{48}$ ne postoji u zemljama s državnim monopolom u osiguranju. ${ }^{49}$ Listu takvih zemalja redovito prati i objavljuje IUMI (International Union of Marine Insurance)..$^{50}$

Nasuprot takvoj praksi, u zemljama razvijenog i slobodnog tržišta prihvaćena je teorija Freedom of Transport Insurance, kao jedna od inačica teorije Freedom of Contract. ${ }^{51}$ Prema toj teoriji, slobodna utakmica među osigurateljima jamči da će se roba osigurati na tržištu koje nudi optimalno pokriće i servis uz najrazboritiju cijenu. To se može postići samo ako su prodavatelj i kupac slobodni u donošenju odluke:

- tko će pribaviti osiguranje robe

- kod kojeg će se osiguratelja osigurati rizik. ${ }^{52}$

Temeljem ugovora o osnivanju Europske unije ${ }^{53}$ i direktivama s područja osiguranja uspostavlja se liberalizacija tržišta osiguranja EU. Uspostavom načela slobode osnivanja (Freedeom of Establishment - FOE) ${ }^{54}$ uklonjene su zapreke koje su onemogućavale osnivanje društva te sada putem posredništva (podružnica, zastupstvo ili ured) osiguratelji mogu izravno nuditi poslove osiguranja u drugoj državi članici. Osim toga, među državama Unije vrijedi načelo slobode pružanja usluga (Freedom of Service - FOS $)^{55}$ pa osiguratelji iz Unije mogu izravno iz svoje matične zemlje osiguravati rizike u drugoj državi članici u kojoj nemaju predstavništvo.

\footnotetext{
47 Prema Vishwanath, K. S., Insuring Cargoes, op. cit., str. 4. O oporezivanju osiguranja u državama članicama Europske Unije v. Šker, Tristan, Slobodan protok kapitala, robe i usluga, Svijet osiguranja, br. 4., 2012. O slobodi sklapanja osiguranja v. Pavić, Drago, Pomorsko osiguranje, Pravo i praksa, op. cit., str. 34. 35.

49 V. Debattista, Charles, Incoterms in Practice, op. cit., str. 94.

$50 \quad$ Lista zemalja objavljena je u ibidem., str. 96.

51 V. Pavić, Drago, Pomorsko osiguranje, Pravo i praksa, op. cit., str. 34.

52 V. Debattista, Charles, Incoterms in Practice, op. cit., str. 92.

53 V. Ugovor o funkcioniranju Europske unije, čl. 56. kojim je zabranjeno ograničavanje slobode pružanja usluga u EU v. Eur-Lex, izvor: https://eur-lex.europa.eu/legal-content/HR/TXT/?uri=CELEX\%3A12016ME\%2FTXT (10. 5. 2018.).

54 V. Šker, Tristan, Slobodan protok kapitala, robe i usluga, Svijet osiguranja, br. 4., 2012.

55 Ibidem.
} 
Pristupanjem Europskoj uniji, hrvatsko tržište osiguranja je također liberalizirano odnosno osigurateljima iz Unije omogućen je liberalniji pristup ulasku na hrvatsko tržište osiguranja. S druge strane, pod istim je uvjetima i hrvatskim osigurateljima omogućen lakši ulazak na tržište Unije. Za sve vrste osiguranja, poslovanje društava za osiguranje EU, pa tako i hrvatskih, uređeno je direktivama i drugim pravnim aktima Unije i to putem tri direktive o neživotnom i jedne direktive o životnom osiguranju. Republika Hrvatska se u procesu pristupanja EU obvezala uskladiti svoje zakonodavstvo sa zakonodavstvom Unije stoga je uskladila odredbe Zakona o osiguranju ${ }^{56}$ s odredbama direktiva. ${ }^{57}$

I prije pristupanja EU, hrvatski osiguratelji su mogli poslove osiguranja u drugim članicama Unije provoditi kroz osnivanje samostalnog osiguravajućeg društva. Članstvom u EU, na području Unije hrvatski osiguratelji mogu provoditi usluge osiguranja još i kroz posredništvo, ali i izravno iz svoje matične zemlje, bez predstavništva. Na isti način osiguratelji iz drugih zemalja članica Unije mogu provoditi poslove osiguranja u Republici Hrvatskoj.

Važno je naglasiti i to da kargo osiguranje prema pravu osiguranja EU spada u kategoriju tzv. large risk, što znači slobodu u izboru prava i jurisdikcije u slučaju spora.

\section{ZAKLJUČAK}

Osiguranje robe u međunarodnom transportu jedno je od gospodarski najvažnijih i ujedno stručno najsloženijih oblika transportnog osiguranja. S ekonomskog motrišta, ono čini važan element vanjskotrgovinskog poslovanja i značajno pridonosi njegovu odvijanju i razvoju. Ugovor o osiguranju robe u međunarodnom prijevozu ima sva obilježja međunarodnog ugovora i to u subjektivnom i objektivnom pogledu. Taj ugovor spada u ugovore privatnog prava, kod kojih se javljaju dva važna pitanja: a) izbora mjerodavnog prava za ugovor u slučaju spora, b) jurisdikcije.

Osnovni je izvor prava za ugovore o međunarodnoj prodaji Konvencija UN o međunarodnoj prodaji robe, 1980. (UN Convention on Contracts for the International Sale of Goods). Odredbe te konvencije dispozitivne su pravne naravi pa stranke mogu pojedina pitanja urediti i drukčije. Za pravno uređenje međunarodne trgovine osobito su važna pravila Međunarodne trgovačke komore (International Chamber of Commerce - ICC), posebice INCOTERMS pravila (2010.) i Jedinstvena pravila i običaji za dokumentarne akreditive, 2007. (ICC Uniform Customs and Practice for Documentary Credits).

Uloga osiguranja robe u međunarodnoj prodaji je višestruka: pruža strankama komercijalnu i financijsku sigurnost da neće pretrpjeti štetu u slučaju ostvarenja nekog transportnog rizika; suvremeno kargo osiguranje omogućuje gospodarstvenicima da osiguraju robu ne samo od uobičajenih transportnih rizika, nego i od raznih dopunskih rizika kojima je izložena roba za vrijeme transporta; korisnoj ulozi transportnog osiguranja posebno pridonosi uloga prenosive pomorske police osiguranja (Marine Insurance Policy), prijenosom koje se s prodavatelja na kupca prenosi i pravo na ostvarivanje naknade štete od osigura-

56 Zakon o osiguranju, Narodne novine, br. 151/2005., 30/2015.

57 V. Stipić, Miro, Hrvatski osiguratelji i tržište osiguranja u EU, Zbornik radova Veleučilišta u Šibeniku, br. 3-4/2014., 2014. 
telja; pomorska polica osiguranja igra važnu ulogu i u financiranju međunarodne trgovine putem dokumentarnog akreditiva; postojanje osiguranja robe pridonosi realizaciji međunarodne prodaje; sva međunarodna pravila za ugovor o prodaji temelje se na pretpostavci da postoji osiguranje robe u transportu. Važnu ulogu u odvijanju međunarodne trgovine imaju i banke koje financijski prate poslove ili se preko njih obavljaju plaćanja, najčešće uz uporabu dokumentarnog akreditiva.

U osiguranju robe osigurani je predmet roba u smislu objekta prijevoza (teret - kargo). Pojam ,roba“ uključuje osim robe trgovačke naravi i svaku drugu tjelesnu pokretnu stvar. Postojanje prijevoznog pothvata bitna je pretpostavka za sklapanje ugovora o osiguranju i za njegovu valjanost. Prije sklapanja ugovora o osiguranju potrebno je provesti odgovarajuće predradnje i metode upravljanja rizicima.

Korisnik osiguranja može biti samo osoba koja ima ili koja može očekivati da će imati opravdani materijalni interes da ne nastupi osigurani slučaj. Opravdani interes za osiguranje ima ona stranka iz ugovora o prodaji koja je nositelj rizika za slučajnu propast ili oštećenje robe. Postojanje interesa za osiguranje utvrđuje se prema pravilu obveznog prava o prijelazu rizika. Praktično, prema rješenjima INCOTERMS pravila MTK.

\section{LITERATURA}

\section{Knjige i akademski članci}

1. Bennet, H. (2006.). The Law of Marine Insurance, Oxford University Press.

2. Bendeković, J. i Aržek, Z. (2008.). Transport i osiguranje, Mikrorad, Ekonomski fakultet, Zagreb.

3. Callol, P. (2017.). Tužbe zbog povrede tržišnog natjecanja prema EU i nacionalnom pravu: transportni sektor u fokusu, Zbornik radova, 2. Međunarodna konferencija transportnog prava i prava osiguranja, Intranslaw, Zagreb.

4. Debattista, C. (1995.). Incoterms in Practice, ICC Publication No. 505(E), Pariz.

5. Dover, V. (1975.). A Handbook to Marine Insurance, 8. ed., Witherby, London.

6. Dunt, J. (2009.). Marine Cargo Insurance, Informa, London.

7. Dunt, J. (2012.). International Cargo Insurance, Informa, London.

8. Frančišković, I. (2004.). Ekonomika međunarodnog osiguranja, Ekonomski fakultet u Rijeci, Rijeka.

9. Gorenc, V., Schwank, F. i Slakoper, Z., (1996.). Međunarodna pravila za kupoprodaju, plaćanja i arbitraže, RRif, Zagreb.

10. Grabovac, I. (2005.). Suvremeno hrvatsko pomorsko pravo i Pomorski zakonik, Književni krug, Split.

11. Hobbs, J. (2003.). Insurance of goods intransit, u Insurance Desputes, 2. ed., LLP, London.

12. Jurić, D. i Mihić, J. (2012.). Prijelaz rizika s prodavatelja na kupca kod ugovora o međunarodnoj kupoprodaji s osvrtom na INCOTERMS 2010., Zbornik Pravnog fakulteta Sveučilišta u Rijeci, br. 1. 
13. Keglević, A. (2014.). Zajednički referentni okvir i europsko ugovorno pravo osiguranja, Dani hrvatskog osiguranja.

14. Kennedy and Rose, The Law of Salvage, Sweet and Maxwell, London, 2002.

15. Lovrić, I. (2011.). Nove institutske klauzule za osiguranje robe, 2009., magistarski znanstveni rad.

16. Lovrić, I. (2012.). Institute Cargo Clauses: Nova verzija 2009., Poredbeno pomorsko pravo, god. 51 (2012.), 166.

17. Lovrić, I. (2017.). Osigurljiv interes prema novim Incoterms pravilima, Zbornik Pravnog fakulteta u Splitu, br. 1/2017.

18. Mlikotin-Tomić, D. (1999.). Pravo međunarodne trgovine, Školska knjiga, Zagreb.

19. Pavić, D. (1986.). Pomorsko osiguranje, Knjiga prva, Croatia osiguranje, Zagreb.

20. Pavić, D. (2005.). Prijenos ugovora o osiguranju, Hrvatska pravna revija, br. 3/2005.

21. Pavić, D. (2005.). Interes osiguranja, Zbornik Pravnog fakulteta u Splitu, br. 79/2005.

22. Pavić, D. (2006.). Pomorsko imovinsko pravo, Književni krug, Split.

23. Pavić, D. (2007.). Prijenos police osiguranja, Svijet osiguranja, br. 1/2007.

24. Pavić, D. (2012.). Pomorsko osiguranje, Pravo i praksa, Književni krug, Split.

25. Petrinović, R. i Plančić, B. (2007.). Hrvatsko pravo spašavanja u uvjetima europskih integracija, Poredbeno pomorsko pravo, br. 161/2007.

26. Petrinović, R. i Lovrić, I. (2012.). Trajanje osiguranja prema Institute Cargo Clauses 2009., Naše more, br. 59(3-4)/2012.

27. Radionov, N. (2009.). Odgovornost cestovnog prijevoznika za robu i poslovi osiguranja, Osiguranje, br. 12/1.

28. Regodić, D. (2014.). Logistika, Univerzitet Singidunum, Beograd, Srbija.

29. Rose, E. D. (2005.). General Average, Law and Practice, LLP, London.

30. Stipić, M. (2014.). Hrvatski osiguratelji i tržište osiguranja u EU, Zbornik radova Veleučilišta u Šibeniku, br. 3-4/2014.

31. Sullivan, E. (1988.). The Marine Encyclopedic Dictionary, London.

32. Šker, T. (2012.). Slobodan protok kapitala, robe i usluga, Svijet osiguranja, br. 4.

33. Todd, P. (1998.). Bills of lading and bankers' documentary credits, LLP, London.

34. Tomašić, V. (1967.). Pravna priroda pomorske izvozne police, Beograd.

35. Tomašić, V. (1987.). Transportno osiguranje, Suvremena administracija, Beograd.

36. Vishwanath, K. S. (2010.). Insuring Cargoes, Witherbys Insurance, Edinburg.

\section{Zakonska pravna vrela}

1. Pomorski zakonik, Narodne novine, br. 181/04., 76/07., 146/08., 61/11., 56/13., 26/15.

2. Zakon o osiguranju, Narodne novine, br. 151/2005., 30/2015.

3. Marine Insurance Act, 1906.

4. Rules for Construction of Policy, First Schedule uz MIA, 1906. 


\section{Internetske stranice}

1. Croatia Osiguranje: http://www.crosig.hr.

2. Euro Star: http://www.eurostar.hr/.

3. Eur-Lex: https://eur-lex.europa.eu/.

4. International Underwriting Association: https://www.iua.co.uk/. 